tion seriously decreased during the winters of 1938-39 and 1939-40 (December to March) and investigations made during 1938 and 1939, when compared with similar ones made in 1933-34 ${ }^{3}$, showed that there was an increase in the percentage of injurious insects eaten from $22 \cdot 0$ to $30 \cdot 5$ per cent, and a slight increase in the percentage of slugs and snails. There was a striking decrease in the percentage of cultivated fruits and fruit pulp, which dropped from $25 \cdot 5$ per cent to 15.2 per cent. Complaints respecting this bird have been very fe' during the past few years.

Thrushes. The missel-thrush and the song-thrush are the only ones that concern us. Of the total food consumed in a year by the former, 30.5 per cent consists of injurious insects and 16.5 per cent of cultivated fruits. The figures for the song-thrush are $32 \cdot 0$ per cent and $15 \cdot 0$ per cent respectively.

Tits. Who it was who first accused the tits of being injurious I do not know, but I fully agree with Yarrell that "none can be more mistaken than these men". The great tit consumes 66.5 per cent of injurious insects per year and 3.6 per cent of fruit, while the blue tit takes $78 \cdot 0$ per cent of injurious insects and 6.0 per cent of fruit.

The above figures need no comment; their significance is patent to every thinking man and woman.

There are certainly a few injurious birds, chief among which are the starling, the house-sparrow and the wood-pigeon. Repressive measures for dealing with these are long overdue.

In 1921 I summed up my investigation ${ }^{4}$ on the starling by stating that, failing some action as there outlined, "the agriculturist and fruit-grower will be left faced with a growing enemy which is devastating their crops and inimical to their interests, and the country with a portentous factor which is adding to the scarcity of home-grown food. In short, the starling has become a plague in the land and a source of great national loss". Observations made during the past eleven years fully bear out this statement.

It has been estimated that the house-sparrow occasions a monetary loss of $£ 50,000,000$ a year. Whether this amount is correct or not is of little matter. What we do know is that they consume a large amount of home-grown food, and if they were reduced to half of their present number, it follows that half of the huge total would be saved.

Before it is too late, it is necessary that the beneficial species I have mentioned above should be scheduled and the destruction of them or their eggs be prohibited. I feel certain if this were done now, even if only as a temporary measure, it would demonstrate once and for all what a powerful factor they are in ensuring prosperous agriculture.

Writing some little time ago I stated", "The 'man in the street' and others in high places may not have realized this, but nevertheless it is true, and unless we do realise the facts and take action our agriculture, forestry and all kindred arts are doomed. These are strong words, but only uttered after a life-time's acquaintance with the subject. . . . The Government and the whole of agricultural Great Britain are evading a great and vital problem of paramount importance to the nation and charged with its future existence."

Long ago the prophet Joel wrote, "Tell ye your children of it, and let your children tell their children. . . That which the palmerworm hath left hath the locust eaten; and that which the locust hath left hath the cankerworm eaten; and that which the cankerworm hath left hath the caterpillar eaten. . . . The field is wasted, the land mourneth ; for the corn is wasted. Be ashamed, $\mathrm{O}$ ye husbandmen, howl $\mathrm{O}$ ye vine-dressers for the wheat and for the barley; for the harvest of the field is perished."

Let us hope that we shall not have to give voice to similar words at the end of 1943 .

1 "The Food of Some British Wild Birds" (1924-27), p. 254.

'J. Min. Agric., 31, 182-186 (1924).

${ }^{3}$ Ibis, 610-613 (1941).

4J. Min. Agric., 27, 1114-1121 (1921).

${ }^{5}$ Nth. West. Nat., 15, 216-218 (1940).

\section{THE ACADEMY OF SCIENCES OF THE U.S.S.R. PROGRAMME FOR 1943}

\section{BY ALEXANDER BAIKOV}

Vice-President of the Academy

$\mathrm{M}$ ORE than in any previous year, the plan of work for 1943 of the Academy of Sciences of the U.S.S.R. is designed to aid the Russian armed forces and war industries in securing a victorious termination of the War. Our main work will be directly concerned with improving armaments and therefore cannot be divulged; but it may safely be said that, if in the past year Soviet physicists, chemists and engineers did much to improve and increase the supply of materials, instruments and tools for war industries, in the New Year they will do considerably more.

Although the scientific effort of the country is almost entirely devoted to war needs, this does not mean that pure scientific research has been suspended. Russian mathematicians and physicists, for example, are continuing their investigations into the theory of numbers, the dynamics of the atmosphere, etc. However, the main effort this year will be focused on mobilizing the material resources of the country and increasing the supply of raw material for war industries. This work is under the direction of the Commission for the Mobilization of the Resources of the Urals, west Siberia and Kazakhstan, under the chairmanship of Vladimir Komarov (of the Academy), the Commission for Mobilization of the Resources of the Middle Volga and Kama Regions, and similar commissions which will make an all-round study of the problems involved. The plan of work of the Academy's geological and geographical department is devoted to exploration and study of new natural resources which may contribute to the country's defensive might, chiefly to the discovery of new deposits of manganese needed for manufacturing various alloys, aluminium, nickel, wolfram and other ores, as well as non-metallic minerals such as fireproof materials, for which there are now great industrial demands. Much work is also planned in locating new oil deposits and increasing the recovery in functioning oilfields. Great hopes are placed in the .Volga-Bashkir expedition. Oil will also be searched for in the Permian Kama coal deposits of the Tatar Republic. As before, considerable attention will be paid to the secondary recovery of oil. Adequate coal supply is just now decisive for industry in the U.S.S.R., and Soviet men of science will make every 
effort to discover new deposits and help to increase the output from those already being exploited. The production of motor fuel from coal and shale of the Urals, Karaganda and the Far East occupies an important place in the plan of work.

Among eminent Soviet men of science who are engaged on the problem of mobilizing the country's natural resources, under the direction of Vladimir Komarov, president of the Academy of Sciences, are Alexander Fersman, Vladimir Obruchev, Alexander Skochinsky, Pavel Stepanov, Lev Shevyakov and Alexander Zavaritsky.

No less important a place in the Academy's plan is held by the problem of increasing the yield of cereal and industrial crops, such as rubber-bearing plants, cotton, sugarbeet, and potato; and also the manufacture of artificial fertilizers. The working out of new industrial processes and the intensification of existing processes constitute the central item in the plans of the Department of 'Technological Sciences of the Academy. Considerable attention will be devoted to the development of the power resources of the eastern regions of the country so as to ensure an adequate supply to the new industrial areas. Efforts will be made to improve industrial gas generating stations, and also to put the gasification of new forms of fuel on an industrial footing, utilizing sources available in various localities and thus obviating the necessity for long hauls of fuel. This will involve working out the principles of design of highly efficient gas-generating installations: The Department will also'deal with problems connected with the economic restoration of the liberated regions.

In chemistry, work will be concentrated this year on industrial utilization of raw materials in the eastern regions, and the manufacture of synthetic rubber, plastics, pharmaceutical preparations, etc. The Institute of Chemical Physics will continue the study of the theory of combustion, which is of cardinal importance in the design of prime movers. Alexander Porai-Koshitz will direct researches into the utilization of the chemical products of coke in industrial plants of the eastern regions. Peter Kapitza will continue his work on the design of a pow่erful machine for making liquid oxygen.

The work of biologists will include investigations on the healing of wounds, and also on the prevention of infectious diseases. It is proposed to treat shock and tetanus on a wide scale by the method of Lina Stern, of the Academy of Sciences, which involves influencing nerve centres by spinal injections. Efforts will be made to discover more effective blood-clotting substances, stimulants, pain-relieving and fatiguerelieving substances.

Historians will engage on a number of interesting investigations, including the history of various nations-the Slavonic history of wars and international relations, the history of the second World War, the history of Russian culture and a chronicle of the present Soviet-German War will occupy chief place. The Department of Languages and Literature is compiling a work on language changes during the present War, a dictionary of modern Russian edited by Sergei Obnorsky, and a study of the mutual influence of Russian and English literature in the nineteenth and twentieth centuries.

The programme of work $I$ have outlined was endorsed by the council of the Academy of Sciences at a meeting held in Moscow under the chairmanship of the president, Vladimir Komarov.

\section{OBITUARIES}

\author{
Prof. Arthur Willey, F.R.S.
}

Dr. Arthur Willey, emeritus professor of zoology in McGill University, Montreal, died on December 26. He was the son of the Rev. William Willey, a leading minister of the west of England. After education at Kingswood School, Bath, he proceeded to University College, London, where in his second year he worked in Lankester's research laboratory. After taking his degree he was sent to the Stazione Zoologica, Naples, where he did research on Tunicates and Amphioxus, afterwards returning to the College as fellow.

Amphioxus was reinvestigated by Willey from every aspect, as it was a key animal in the controversies on the ancestry of vertebrates. In opposition to Cuvier's four types of structure, Saint-Hilaire sought a unity of plan homologizing insects and vertebrates, Leydig especially comparing their brains. Kowalevsky followed in 1866 with researches on Amphioxus, but in 1875 Semper and Dohrn independently maintained an annelid ancestry for vertebrates. In the early nineties most schools of zoology seriously discussed all these views, but in 1894 Willey's book, "Amphioxus and the Ancestry of the Vertebrates", caused almost a revolution. He had tried his matter out in a course of lectures at University College, when he had insisted on his practical work including every stage in the development and structure of Amphioxus in comparison with Ammocotes.

At this time the leading zoologists of Great Britain became excited about the Pearly Nautilus. This "pretertiary creation" had been re-examined by Graham Kerr, following on work by Thering and Ray Lankester, and a knowledge of its embryology was desired. To this end the managers of the Cambridge Balfour Fund elected Willey their student and continued him for five years. Nautilus had first been described by the great Dutch naturalist Rumphius, together with many Malayan 'plant animals'. Owen was excited by the anatomy of a later specimen, but Cuvier did not live to see it in the flesh. Its shell had been known from the time of Aristotle, but it was always compared with that of the argonaut, which floats on the sea-surface in connexion with the development of its eggs. It was supposed to be related to Spirula, the soft parts of which were equally scarce, although its shell is common on tropical beaches. This form, however, has a floating life with a shell that has been reduced to a minimal weight and size and has become almost internal, whereas Nautilus is a ground feeder in comparatively deep water with an immense shell, the animal being in a terminal chamber out of which its crawling and feeding tentacles protrude; its flattened shell is held upright on the ground. Specimens which had floated to the surface, on which the early anatomy had been studied, were mostly moribund. Willey trapped specimens in relatively deep water; the bait was mashed-up crayfish wrapped in coconut fibre so as to be invisible to the animal, which proved to be attracted by smell, its pinhole eye not being the efficient eye of most cuttle fish. The necessary breeding for the embryology did not succeed with the means at Willey's disposal, but the anatomical account published in the "Zoological Results" of his expedition is classical.

The scene of Willey's first labours was in Blanche Bay, New Britain, now known as Rabaul. It is a 